\title{
Effect of feeding level and diet composition on microbial protein synthesis and in vivo feed protein degradability in the rumen of sheep
}

\author{
D Djouvinov, $\mathrm{N}$ Todorov
}

University of Zootechnics and Veterinary Medicine, Stara Zagora, BG 6000, Bulgaria

In ruminant nutrition the changes in the feeding level are most often connected with changes in diet composition. Both factors might alter microbial protein synthesis (MPS) and feed nitrogen degradability $(\mathrm{Ndg})$ in the rumen.

The study aimed to examine the effect of the feeding level and roughage : concentrate ratio on MPS and Ndg in the rumen of sheep.

Seven treatments, differing by the forage : concentrate ratio $(20: 80,50: 50$ and $100: 0)$, the feeding level ( $1 \mathrm{M}, 1.4 \mathrm{M}$ and $2 \mathrm{M}$ ) and the inclusion of polyvinylchloride (PVC) were fed to duodennaly cannulated mature wethers. Each diet was tested in separated experimental period with 3 wethers. PVC was added as an inert material (powder-like structure) to $1 \mathrm{M}$ mixed diets to increase the level of dry matter intake (DMI) without changes in the nutrients intake. Total duodenal digesta flow was measured during $48 \mathrm{~h}$ collection period. Microbial nitrogen (MN) supply to the small intestine was estimated on the base of purine derivatives excretion in urine as proposed by Chen et al (1990, Br J Nutr, 63, 131-142). Urine was collected during a $7-d$ period. Ndg in vivo was calculated on the base of difference between total non-ammonia nitrogen (NAN) and $\mathrm{MN}$ reaching duodenum.

Increasing feeding level increased daily flow of $M N$ to duodenum and efficiency of MPS (Emps, g MN $/ \mathrm{kg}$ digestible organic matter in the rumen - DOMR) when diets with $80 \%$ barley $+20 \%$ hay were fed. Rise of DMI at the same nutrients consumption (diet $1 \mathrm{M}+\mathrm{PVC}$ vs diet $1 \mathrm{M}$ ) led to increasing $M N$ flow to duodenum and Emps. Tendency for the same changes were found for diets with $50 \%$ barley $+50 \%$ hay. Probably, $1 \mathrm{M}$ diets with $50: 50$ hay:barley ratio benefited MPS and higher values of Emps were obtained compared to diets with $80 \%$ barley $+20 \%$ hay. Feeding high concentrate diets with $50 \%$ and $80 \%$ barley at 1.4 and $2 \mathrm{M}$ level slightly decreased Ndg compared to $1 \mathrm{M}$ diets.

Contribution of each of two feeds, included in the diets, to MPS and Ndg was calculated by algebraic solutions from equations with two unknowns. The equations base on different ratio of feeds in experimental diets. The change of feeding level from $1 \mathrm{M}$ to 1.4 and $2 \mathrm{M}$ increased the contribution of hay to daily MN supply to the small intestine from 1.3 to2.5 $\mathrm{g} \mathrm{MN} / 100 \mathrm{~g}$ organic matter (OM), respectively. The increase in DMI by inclusion of inert material (PVC) in the diet at the same energy level (1M) led to higher contribution of barley and lower contribution of hay to the total MN supply to duodenum. Intake of $100 \mathrm{~g} \mathrm{OM}$ from alfalfa hay corresponded to $0.8 \mathrm{~g} \mathrm{MN}$ without PVC in the diet and to 1.3 MN g with PVC. Intake of $100 \mathrm{~g} \mathrm{OM}$ from barley corresponded to $1.9 \mathrm{~g} \mathrm{MN}$ with PVC and 1.1 MN g without PVC.

MPS in the rumen supplied by barley and hay changed into different directions when diet composition and feeding level differed.

\begin{tabular}{|c|c|c|c|c|c|c|c|}
\hline Feeding level (M) & $1 \mathrm{M}$ & $1 \mathrm{M}$ & $2 \mathrm{M}$ & $1 \mathrm{M}$ & $1 \mathrm{M}$ & $1.4 \mathrm{M}$ & $1 \mathrm{M}$ \\
\hline Hay:barley & $20: 80$ & $20: 80+P V C$ & $20: 80$ & $50: 50$ & $50: 50+P V C$ & $50: 50$ & $100: 0$ \\
\hline$N$ intake $(g / d)$ & 12.1 & 12.1 & 24.3 & 16.9 & 16.9 & 24.9 & 20.4 \\
\hline NAN flow to duodenum $(\mathrm{g} / \mathrm{d})$ & 8.8 & 12.1 & 21.0 & 12.5 & 13.7 & 25.3 & 17.0 \\
\hline MN & 6.4 & 9.5 & 15.4 & 8.3 & 9.3 & 18.1 & 10.0 \\
\hline feed $\mathbf{N}$ & 2.4 & 2.6 & 5.6 & 4.2 & 4.4 & 7.2 & 7.0 \\
\hline Emps (g MN/kg DOMR) & 19.4 & 25.8 & 30.9 & 25.6 & 31.4 & 42.3 & 29.1 \\
\hline $\operatorname{Ndg}(\%)$ & 80.1 & 78.3 & 77.1 & 75.2 & 74.2 & 71.1 & 65.9 \\
\hline
\end{tabular}

